\title{
Legal Framework of Poverty Reduction in Bangladesh: An Analysis From The International Human Rights Law
}

\author{
Md. Golam Mostofa Hasan
}

\section{Introduction}

Poverty still haunts millions of people all over the world even in this twenty first century. Eradication of poverty from every corner of the world has become a major challenge for the global community. With the emergence of international human rights law, which guarantees minimum level of human dignity, the concerns regarding global poverty has mounted top-hill, arguing poverty is denial of such human dignity. Recently a conceptual framework, i.e., 'Rights Based Approach' is developing to address this global challenge of poverty eradication, in accordance with international human rights norms and standards. The Rights Based Approach has been widely endorsed by global experts, different agencies of the United Nations and other global and regional bodies who work for poverty eradication and upliftment of human rights. This 'Rights Based Approach' is to assist to frame principles and policies of poverty reduction programs and their implementation for a particular country. Many countries in the world have already incorporated this approach in their national poverty reduction strategy.

This paper mainly focuses on the adoption of the 'Rights-Based Approach' in the policy-programs of poverty reduction efforts in Bangladesh. Since identification of poor is prerequisite for any poverty reduction policy, the paper elaborates the very concept of poverty in general terms as well as in the context of the international human rights law and finds that the 'capability poverty' is the best appropriate notion to define poverty under human rights standards. It finds that there is a clearly established link between human rights and the concept of poverty. After due consideration of these poverty scenario, it concludes that the real cause of poverty in Bangladesh is not 'limited resources' but 'unequal distribution of resources'. The fact that progress in poverty reduction rate is much slower than it has been planned remains unexplained. Bangladesh fails to achieve its planned growth in poverty reduction sector mostly because of 'structural injustice' and 'inefficiency' in the implementation level. To cure these setbacks, this paper suggests adopting 'human rights based approach' inevery process of policy making, adoption and implementation of those poverty reduction programs. The paper will vigorously focus on how 'human rights based approach' helps attaining desired outcome in

'Lecturer, Department of Law, University of Barisal. 
accelerating poverty alleviation by curing setbacks of implementation phase and thus ensuring less unequal income distribution and reducing extreme or hard-core poverty. The research paper is based on analytical method, purely based on my own reading, observation and experience and experts opinion.

\section{The Concept of Poverty}

Any strategy for poverty reduction has to begin with the identification of the poor. ${ }^{1}$ For this task, first, we need to find out an acceptable definition of what constitutes poverty and the population who fall in it. Since 'poverty' has multidimensional and cultural-relative concept, the attributes of poverty depends on the social, economic, political and cultural value system of a particular society. Therefore, in order to define poverty, the specific local and contextual experience of particular region or country must be inferred. As Voices of the Poor: Can Anyone Hear Us?, the compelling World Bank study, puts it: "Poverty is experienced at the local level, in a specific, context, in a specific place, in a specific interaction." 2 To have a good definition of poverty is a precondition for adopting comprehensive and fruitful poverty reduction programs locally in particular region. It is also relevant to determine which approaches to define poverty best suits norms of international human rights law.

\subsection{Kinds of poverty}

At present there are three basic approaches to define poverty, i.e. a) Income poverty, b) Capability poverty, and c) Social exclusion.

\subsubsection{Income poverty}

Poverty has been conventionally viewed as the lack of income or purchasing power or deprivation of resources to attain the basic necessities of life. Even within this usual definition of poverty, there are several disagreements in conceptual terms and even greater ones regarding how to measure it. ${ }^{3}$

1 OHCHR, Principles and Guidelines for a Human Rights Approach to Poverty Reduction Strategies, Geneva, United Nations, 2005, p. 7. See also, OHCHR, Draft guidelines: A Human Rights Approach to Poverty Reduction Strategies, Geneva, United Nations, 2002, p. 3.

<www.unhchr.ch/development/povertyfinal.html.> (last access 10 Nov. 2011)

${ }^{2}$ D. Narayan with R. Patel, K. Schafft, A. Rademacher and S. Koch-Schulte, Voices of the Poor: Can Anyone Hear Us? Vol. 1, New York, Oxford University Press, New York, 2000, p. 230.

${ }^{3}$ Commission on Human Rights, Economic, Social and Cultural Rights, Human Rights and extreme poverty, Report of the independent expert on the question of human rights and extreme poverty by ArjunSengupta. UN DOC: E/CN.4/2005, 11 Feb. 2005, from now on cited as Independent Expert Report 2005. 
According to Jeffrey Sachs, there is an agreement on the distinction of three different types of income poverty: Extreme (or absolute) poverty ${ }^{4}$, moderate poverty ${ }^{5}$, and relative poverty.

The World Bank uses this paradigm by measuring a person's income and establishing a "poverty line" (US \$1 a day measured in purchasing power parity) which represents an income level below which a person is held to be in extreme poverty. Another World Bank category, income between US $\$ 1$ per day and US \$2 per day, can be used to measure "moderate poverty".

\subsubsection{Capability poverty}

Capability view of poverty is perfectly consistent with the human rights approach. ${ }^{8}$ According to this view, poverty can be said to consist of the non-fulfillment of a person's human rights to a range of basic capabilities. ${ }^{9} \mathrm{~A}$. Sen puts poverty as "the failure of basic capabilities to reach certain minimally acceptable levels". ${ }^{10}$ The concept of capability refers to a person's freedom to achieve well being which consists of some interrelated functionings, i.e. things we value being or doing---such as being in good health, being literate or being able to participate in the life of a community or being free to speak etc. ${ }^{11}$

However,

...not all kinds of capability failure would count as poverty. Since poverty denotes an extreme form of deprivation, only those capability failures would count as poverty that are deemed to be basic in some order of priority. Different communities may of course have different orders of priority and hence a different listing of what

\footnotetext{
${ }^{4}$ Extreme poverty means that households cannot meet their basic needs for survival for example- they are chronically hungry, unable to access health care etc. Unlike moderate and relative poverty, extreme poverty occurs only in developing countries.

${ }^{5}$ Moderate poverty generally refers to conditions of life in which basic needs are met, but just barely.

${ }^{6}$ Relative poverty generally construed as a household income level below a given proportion of average national income. The relative poor, in high income countries, lack access to cultural goods, entertainment, recreation, and to quality health care, education, and other prerequisites for upward social mobility.

${ }^{7}$ J. D.Sachs, The end of poverty, economic possibilities for our time. New York, the Penguin Press, 2005, p. 20.

${ }^{8}$ OHCHR, Draft guidelines: A Human Rights Approach to Poverty Reduction Strategies, Geneva, United Nations, 2002, p. 3.<www.unhchr.ch/development/povertyfinal.html.> (last access 10 Nov. 2011)

${ }^{9}$ For details, see supra note- 1.

${ }^{10}$ A. Sen, Inequality Re-examined, Cambridge, Harvard University Press, 1992, p. 54.

${ }^{11}$ For details, see OHCHR, Human Rights and Poverty Reduction: A Conceptual Framework, New York and Geneva, United Nations, 2004, p.7.
} 
would qualify as 'basic' capabilities. To that extent, there is some degree of relativity in the concept of poverty. But from empirical observation it is possible to identify certain basic capabilities that would be common to all - for example, being adequately nourished, being adequately clothed and sheltered, avoiding preventable morbidity, taking part in the life of a community, and being able to appear in public with dignity. ${ }^{12}$

The Human Rights-Based Approach suggests that "in each country, it must be ascertained, through a participatory process, which other capabilities its people consider basic enough for their failure to count as poverty". ${ }^{13}$

\subsubsection{Social exclusion}

In the 1970s the concept of social exclusion came into the literature to analyze the condition of those who are not necessarily income-poor -though many are too- but who are kept out of the mainstream of society. ${ }^{14}$ The European Foundation described it as "the process through which individuals or groups are wholly or partially excluded from full participation in the society in which they live" ${ }^{\prime 15}$. In the Human Poverty Index (hereinafter mentioned as HPI), the indicator for social exclusion is unemployment and it is exclusively measured in industrialized countries.

UNICEF is proposing a shift in the definition of poverty - away from a narrow measurement that addresses income exclusively to a definition that includes income poverty, deprivation and well-being. ${ }^{16}$

\section{2'Poverty': How It Is Defined in Bangladesh}

Till date, conceptualization of poverty in Bangladesh's policymaking is limited to income/consumption poverty where rise or fall of income above or below a predefined poverty line determines changes in poverty reduction rate. All the Household Expenditure Surveys (HESs) carried out in Bangladesh from 1973-74 to FY1991-92 has used Food Energy Intake (FEI) and Direct Calorie Intake (DCI) methods in order

\footnotetext{
${ }^{12}$ Ibid, p.7.
}

${ }^{13}$ OHCHR, Principles and Guidelines for a Human Rights Approach to Poverty Reduction Strategies, Geneva, United Nations, 2005, para.32. It also categorically describes a number of capabilities that are common to every society irrespective of their divergent composition.

14 Nathaniel O. Agola, and Joseph L. Awange, Globalized Poverty and Environment: 21st Century Challenges and Innovative, Springer, New York, 2014, p. 83.

${ }^{15}$ European Foundation for the Improvement of Living and Working Conditions.Public welfare Services and Social Exclusion: the Development of Consumer Oriented Initiatives in the European Union, Dublin, 1995.

${ }^{16}$ UNICEF, in a News Note dated 25 February, 2009;

<http://www.unicef.org/infobycountry/media_51925.html>(last access 10 Nov. 2011). 
to measure the incidence of income poverty. ${ }^{17}$ In the HES conducted in 1995-1996, the BBS for the first time adopted the Cost of Basic Needs (CBN) method. Similarly, in the Household Income and Expenditure Surveys (HIES) of 2000 and 2005 and 2010, CBN method was used. With this method, non-food consumption is also considered for constructing poverty index. Thus, Bangladesh is gradually adopting wider definition of poverty to include various dimensions of poverty.

The official Bangladesh Poverty measurement includes two types of poverty lines: i. Upper Poverty Lines, and ii. Lower Poverty Lines. ${ }^{18}$ An 'upper poverty line' represents a higher level of per capita household expenditure than a 'lower poverty line'. As a result, if an 'upper poverty line' is adopted, more household and individuals are defined as poor than if a lower poverty line is adopted. In Bangladesh, the upper poverty lines are on average 20 percent higher than the lower poverty lines. ${ }^{19}$

At present, a slight shifting towards capability approach in defining poverty is seen at the official website of Ministry of Finance whichhas mentioned 'human poverty' to address poverty resulted from lack of 'human development' ${ }^{20}$ It may be regarded as an opening door so as toincorporate 'capability approach' to the full extent which match with the international human rights standards.

\section{Poverty and Human rights}

The link between poverty and human rights has been clearly established ${ }^{21}$ and sophisticated by numerous authors and global experts on human rights. However, there are considerable disagreements among the experts on the extent and the process of interlink between them. The debate over the extent and the process of inter-link mainly centers on two conceptual frameworks- i) poverty itself is a denial or violation of human rights, and ii) poverty as a cause or consequence of human rights denials or violations. These two approaches though not incompatible, rather

\footnotetext{
${ }^{17}$ Bangladesh Economic Survey, 2011, p. 193.A person having daily calorie intake of less than 2122 kilo-calories used to be considered to be in absolute poverty and 1805 kilo-calories in hard-core poverty.

${ }^{18} \mathrm{BBS}$ <http://www.bbs.gov.bd/WebTestApplication/userfiles/Image/UpdatingPovertyMapsofBangladesh.pdf> (last access 10 Nov. 2011)

${ }^{19}$ Ibid.

${ }^{20}$ Ministry of Finance, Official Website, <www.mof.gov.bd/en/budget/12_13/prsp/Poverty_definition.pdf> (last access 1 Apr. 2014).

${ }^{21}$ In 1948, the Universal Declaration of Human Rights established that poverty is a human rights issue. Since the mid 1990s, there has been increasing recognition of poverty as a human rights problem.
} 
sometimes overlapping, attract serious notice as to their different legal obligations of states and other actors. ${ }^{22}$

\subsection{Poverty itself is a denial or violation of human rights}

This approach sees poverty as incompatible with human dignity. Given that human dignity is the foundation for human rights, poverty is therefore a denial of all human rights. ${ }^{23}$ The Committee on Economic, Social and Cultural Rights of the UN holds the firm view that poverty constitutes a denial of human rights. ${ }^{24}$ However, this point, if taken as normative principle, throws some serious practical questions, especially to the legal obligations of the state and other actors.

International human rights practitioners still lack conceptual clarity in what is exactly meant by the statement that poverty violates human rights, especially from an international human rights law perspective. Experts are trying to find the answers of some crucial questions in this regard, i.e., whether the statement that poverty violates human rights is a rhetorical declaration expressing moral condemnation or is it a legal claim. If it were a legal claim, what would be the legal consequences for states and other duty holders?

Can the denial of certain rights be described as poverty? Are those rights codified under human rights law? Do they entail binding obligations for identified duty-bearers? Are those duties of plausible compliance? All these questions are complicated, and if they cannot be solved both in theory and practice, "the notion of poverty as a violation of human rights cannot be taken as more than an empty and ineffective slogan". ${ }^{25}$

\footnotetext{
${ }^{22}$ F. D. Costa, "Poverty and Human rights: from Rhetoric to Legal Obligations a Critical Account of Conceptual Frameworks", International Journal on Human

Rights, \ttp://www.surjournal.org/eng/conteudos/getArtigo9.php?artigo=9, artigo_doz.html>( last access 10 Nov. 2011)

${ }^{23}$ Ibid.Mary Robinson, Paul Hunt, Manfred Nowak, SiddiqOsmani, AmartySen, the international organizations dealing with poverty and human rights, UNDP, OHCHR, the Commission on Human Rights etc agree that poverty isthe violation of human rights. See, M. Robinson in her preface to the OHCHR,Draft Guidelines: A Human Rights Approach to Poverty Reduction Strategies, Preface, 2002. <www.unhchr.ch/development/povertyfinal.html> (last access 10 Nov. 2011); H, P. Nowak, and S. Osmani, Human Rights and Poverty Reduction, a conceptual framework, OHCHR, HR/PUB/04/1. 2004, p.7; UNDP,Poverty reduction and human rights: a practice note, 2003. $<$ http://www.undp.org/poverty/practicenotes/povertyreduction-humanrights0603.pdf. $>$ (last access 10 Nov. 201). OHCHR, Human Rights and Poverty Reduction, a conceptual framework, New York and Geneva, 2004, <http://www.unhchr.ch/html/menu6/2/povertyE.pdf>(last access 10 Nov. 2011).

${ }^{24}$ The Committee on Economic, Social and Cultural Rights,UNO, The nature of States parties obligation, General Comment 3, UN Doc. HR1/GEN/1/Rev.1, 1990, p. 45.

${ }^{25}$ Supra note- 2 .
} 
The answers are not clarified yet. Even if the right to be free from poverty is recognized as a human right and binds the state legally, it is not practically plausible to implement. Since there is no treaty ${ }^{26}$ accepting poverty as denial of human rights and enumerating the legal consequences for the actors whose actions or failure cause poverty and there exist no effective mechanism either national or global to enforce the violations due to poverty. Given all these normative and operational fallacy, this notion- to consider poverty per see violation of human rights is the least clear, accurate and helpful.

\subsection{Poverty as a cause or consequence of human rights denials or violations}

This conceptual approach conceives poverty as the cause for violations of many human rights, which include both ESC (economic and social rights), and CP (civil and political rights). The difference with the first approach is that under this approach, poverty is not considered a priori of human rights violation but a cause of human rights violations (because it socially excludes a group of people whose human rights are then systematically violated). It is also suggested that poverty is not the violation of one human right such as the right to development, the right to an adequate standard of living or a combination of several others; but as a factual situation that may cause or be the result of several human rights violations. ${ }^{27}$

The Vienna Declaration has characterized extreme poverty as a violation of human dignity, ${ }^{28}$ but avoided calling it a violation of human rights, arguably because of the reluctance of governments to accept legal responsibility. It observed that the "existence of widespread extreme poverty inhibits the full and effective enjoyment of human rights" ${ }^{29}$ It is more realistic to conceptualize poverty as a situation where human rights are unlikely to be fulfilled and the fight against poverty as a beneficial atmosphere to the achievement of human rights. However, poverty is not per se a violation of human rights, since there are several conceptual steps before naming poverty as a human rights violation. Philip Alston, for example, considered poverty as a violation of human rights only in the following cases-

- To the extent that a government or other relevant actor has failed to take measures that would have been feasible ("to the maximum of its available resources", as the language of the ICESCR puts it); and

\footnotetext{
${ }^{26}$ The Vienna Declaration has characterized extreme poverty as a violation of human dignity but avoided calling it a violation of human rights, arguably because of the reluctance of governments to accept legal responsibility.

${ }^{27}$ Supra note- 2 .

${ }^{28}$ Vienna Declaration and Programme of Action, adopted by the World Conference on Human Rights on

${ }^{25}$ June 1993 (UN DOC: A/CONF.157/23).

${ }^{29}$ Supra note- 2 .
} 
- Where those measures could have had the effect of avoiding or mitigating the plight in which an individual living in poverty finds him or her. ${ }^{30}$

Similarly, Arjun Sengupto, the former UN Independent Expert on Human Rights and Extreme Poverty ${ }^{31}$ argued that poverty cannot be defined as the absence of human rights as these two concepts are not equivalent. According to him, the link between the two concepts is not straight forward, since-

The space of 'capability' (the denial of which constitutes poverty) is much broader than human rights. Poverty can be alleviated and human rights still violated. However, if human rights are realized there may not be any poverty. ${ }^{32}$

He suggested that it would be more accurate to consider poverty eradication as playing an instrumental role in creating conditions of well-being for the rights holder. ${ }^{33}$ Thus, there are several steps from denial to violation..$^{34}$

- Firstly, to identify concrete programs of action that are technically possible and institutionally viable (such as resource constraints and rules of international transactions).

- Secondly, to identify duty holders and their specific duties, which if fully carried out would implement those programs.

It is also argued that even if such duty holders do not have direct responsibility for creating conditions of poverty it would be possible to say that the duty bearers are violating their obligations to fulfill the rights if there are feasible programs and they are not implementing them. ${ }^{35}$

Poverty erodes or nullifies economic and social rights such as the right to health, adequate housing, food and safe water, and the right to education. It is similarly true, regarding civil and political rights, such as the right to a fair trial, political participation and security of the person.

Then, it is clear that none of the human rights- civil, political, economic or social will be fulfilled in a poverty scenario. The complexities of the phenomenon of poverty,

${ }^{30}$ H. J. Steiner and P. Alston, International Human Rights in Context: Law, Politics and Morals, Oxford, 2005, p. 787.

${ }^{31}$ UN DOC: E/CN.4/2006/43, 2 Mar. 2006.

${ }^{32}$ Ibid.

${ }^{33}$ Ibid.

${ }^{34}$ Supra note- 2

${ }^{35}$ Ibid. 
especially the diverse causes which are not always within the state's control, make it very difficult to assume that poverty implies human rights violations without further inquiries. Therefore, the position which views poverty as a cause for violation of human rights is both theoretically and practically more realistic and legally accurate than the previous one. ${ }^{36}$ This fundamental recognition regarding poverty as denial of human rights is reshaping the international community's approach towards formulating and implementing the poverty reduction initiatives.

\section{4. 'Human Rights Based Approach' to Poverty Reduction: Integrating Human Rights to Poverty Reduction Policymaking and Implementation Process at Minimum International Threshold}

The right to development has recently been recognized as one of the fundamental human rights through 'UN Declaration on the Right to Development (1986)'.Since that time the traditional notion of 'development' is being gradually shifted towards 'enlarging people's choices in life, expansion of human freedoms and capacity building' instead of 'generating income' only. With this shift in international development discourse, poverty alleviation programs also took a new turn. The world has already witnessed that the traditional service-oriented policies and the billions of dollars being spent as foreign aid had not succeeded in eliminating poverty worldwide. The idea that economic growth is the key aspect of poverty relief has been challenged and aspects such as human dignity and the universality of human rights are emphasized now in the development agenda. Amartya Sen's Development as Freedom was very influential for this new line of thought. To put this thought into practice, the concept 'Human Rights Based Approach' or simply 'Rights Based Approach' is gaining scholastic endorsement as an effective and concrete measure to mainstream human right sin various development programs so that the marginalized may be empowered and the standard of their life is improved. In line with this academic backing, the 'rights based approach' is also being adopted in development policies and programs by International Organizations, including different agencies of United Nations, NGOs, even by state governments.

A 'rights-based approach' ${ }^{37}$ to development is a conceptual framework which is based on international human rights standards and directed to promoting and

\footnotetext{
${ }^{36}$ Ibid.

- According to Sen, development is considered a process of expanding human freedoms, the assessment of development has to be informed by this consideration. Measuring development in terms of GNP growth or level of industrialization is 'simply not enough'.

${ }^{37}$ Mary Robinson, Paul Hunt, Manfred Nowak, Siddiq Osmani, Amarty Sen etc. under the auspices of different human rights agencies of UN are the pioneer of this thought. For details, please see, O. Nowsosad, A Human Rights Based Approach to Development: Strategies and Challenges, OHCHR; OHCHR, Principles and Guidelines for a Human Rights Approach to Poverty Reduction Strategies, Geneva, United Nations, 2005; OHCHR, Draft guidelines: A Human Rights Approach to Poverty
} 
protecting human rights. A rights-based approach integrates the norms, standards and principles of the international human rights system into the plans, policies and processes of development. The norms and standards are based on those contained in international treaties and declarations. There is a consensus on the following basic elements of rights-based approach (hereinafter mentioned as RBA) to development -

* Express linkage to rights

* Accountability of all actors- local, national and global.

* Empowerment

* Participation

* Non-discrimination and attention to vulnerable groups

This article avoids in detailing all those elements. However, it will substantiate the basic characteristics or advantages of incorporating the RBA in poverty alleviation programs, focusing the present context of Bangladesh.

Primarily, the RBA is a people-centered approach. Its primary and final goal is to give people the power, capacities, capabilities, and access necessary to change their own lives, improve their own communities, and influence their own destinies. It is home-grown policy initiative which is implemented with consideration of local context. Since, poverty is also a local phenomenon, the RBA is appropriate policyapproach to formulate plans and process of poverty reduction programs.

Rights-based approaches are comprehensive in their consideration of the full range of indivisible, interdependent and interrelated rights: civil, political, economic, social and cultural. A rights based approach does not condone development policies that violate rights, and they permit no "trade-off" between development and rights. ${ }^{38}$ This approach requires higher degree of participation of all quarters of a society, mainly the marginalized. This participation must be active, independent, and meaningful. Routine or going through the motion contacts with beneficiaries are not sufficient.

Rights-based approach gives due attention to issues of accessibility, including the issue relating to development processes, institutions, information and redress or complaints mechanisms - many of which fall clearly within the purview of national human rights institutions. It combines both positive and negative notion of rights- to protect rights and to prevent violation of those rights. It identifies the root causes including social practices, laws, leadership, institution set which might contribute to those violations. This identification contributes to the establishment of adequate laws, policies, institutions, administrative procedures and practices, and mechanisms of redress and accountability to deliver on entitlements and respond to denial and violations. These will include the judiciary, effective parliamentary mechanisms,

Reduction Strategies, Geneva, United Nations, 2002, OHCHR, Human Rights and Poverty Reduction: A Conceptual Framework, New York and Geneva, United Nations, 2004.

${ }^{38}$ Ibid. 
national human rights institutions, and a vibrant civil society. So, RBA also strongly advocates institutional reforms for effective implementation. Finally, it determinations whether and how the benefits of development are fairly distributed, who in particular benefits, and who is excluded.

\section{Poverty Scenario in Bangladesh}

The Bangladesh Bureau of Statistics (BBS) brought two reports, namely- a preliminary report on the "Household Income \& Expenditure Survey (HIES), 2010." The second was the preliminary results of the "Population \& Housing Census 2011." The latest HIES was conducted from February 1, 2010 to January 31 in 2011, based on people's basic needs. In this survey Cost of Basic Needs (CBN) method instead of Daily Calorie Intake (DCI) method was used. The Population and Housing Census reported that there were 142.3 million people in Bangladesh, making it by most counts the $8^{\text {th }}$ most populous country in the world. ${ }^{39}$ In fact, the figure is conservative compared to that of the World Bank's "World Development Indicators," which puts the population at 162.2 million.

According to the HIES for 2010, $17.6 \%$ of the country currently lives in extreme poverty. ${ }^{40}$ Combining just these BBS figures equates to approximately 25 million extremely poor people in Bangladesh. To put this figure in context, if all the extreme poor people of Bangladesh were a separate country, they would be the $53^{\text {rd }}$ largest country by population in the world. ${ }^{41}$ Again if we use the upper poverty line, then there are almost 45 million Bangladeshis still living below this threshold. ${ }^{42} 33$ million children in Bangladesh- about half of all Bangladeshi children are living in poverty while about one in four children is deprived of at least four basic needs among the following: food, education, health, information, shelter, water and sanitation. ${ }^{43}$

However, poverty declined to 31.5 percent in 2010 from 40 percent in 2005. Since 2005 (the last HIES) the incidence of extreme poverty in the country has decreased from $25.1 \%$ to $17.6 \%$. Rural poverty declined to 35.2 percent in 2010 from 43.8 percent in 2005, while urban poverty slid to 21.3 percent from 28.4 percent in the same period. Per year poverty reduction during 2000-2005 was around $1.78 \%$, which improved to $2 \%$ during 2005-2010. From these reports, it is very much apparent that

\footnotetext{
${ }^{39}$ J. Perry, "New Statistics: 25 million in extreme poverty", Daily Star, 8 Oct. 2011, <www.thedailystar.net/newDesign/archive.php?>(last accessed 10 Dec. 2011)

${ }^{40}$ 'Extreme poverty' is defined as those people whose total expenditure is equal to the food poverty line (the cost of a basket of goods amounting to the consumption of 2,100 Kcal per person day).

${ }^{41}$ Supra note- 1.

${ }^{42}$ Ibid.

${ }^{43}$ UNICEF, in a News Note dated 25 February, 2009;

$<$ http://www.unicef.org/infobycountry/media_51925.html> (last access 10 Dec. 2011)
} 
the country is making excellent progress in poverty reduction, and also compared with many other countries, the trend of poverty reduction in Bangladesh has indeed been impressive.

Inequality (Gini) of per capita income stood at 0.458 in 2010 , which was 0.467 in 2005. If we follow the GDP growth during the last five years, poverty should have decreased to $27-28 \%$. However, due to global recession and natural calamities locally, it didn't happen. It is said that $1 \%$ increase in GDP should result in $0.6 \%$ reduction in poverty level. Keeping that in cognizance, I would think $31-32 \%$ poverty rate according to recent HIES is convincing.

From these reports, it is clear that Bangladesh has come a long way in poverty reduction which cannot be denied. However, a large portion of population still remains under lower poverty line and they are outside the benefits of economic growth and development. The statistics is based on basically income poverty, and if it is measured on capability poverty, the percentage of population under the poverty line will be much higher than the present 31.5 percent.

A major concern from the recent survey is that extreme poverty has decreased slower than moderate poverty, suggesting that those most in need are still failing to reap the benefits of the widespread economic growth in the country. ${ }^{44}$ The 'extreme poor', in the society are still marginalized. They are not empowered enough to participate in the development cycle. The benefits do not reach this most vulnerable portion of our population. $^{45}$

\section{Poverty Reduction Programs and Initiatives in Bangladesh}

Elimination of poverty and income disparity has been at the forefront of Bangladesh development policy. In order to achieve a sustainable poverty reduction, the country at present implementing 'Sixth Five Year Plan' for 2011-1015under 'Outline Perspective Plan for 2010-2021', popularly referred as 'Vision 2021'. Before this, mostly, in order to conform the mandatory prescription from the World Bank, Bangladesh has implemented 'Interim Poverty Reduction Strategy Paper' (IPRSP) during FY 2003-FY 2004. The then Government thereafter decided to adopt a full blown PRSP as a strategy for pursuing Bangladesh's development objectives for poverty reduction, and accordingly the first 'National Strategy for Accelerated Poverty Reduction'(NSAPR) was implemented during the period FY 05 to FY 07, tenure of which was extended up to FY 2008. Thereafter, the Caretaker Government prepared and approved the Second NSAPR for the period FY 09 to FY 11.

Bangladesh has also target plan to achieve Millennium Developmental Goals for poverty reduction by 2015 . It is on track to achieve MDG 1 (halving the proportion

\footnotetext{
${ }^{44}$ Supra note- 1

${ }^{45}$ Ibid.
} 
of population below national poverty line and minimum level of energy consumption) and the achievement of this MDG-1 is expected to be possible by $2017{ }^{46}$ The vision of the present government is to reduce the poverty level to 15 per cent by $2021 .^{47}$

The Government of Bangladesh also runs various selected programs for poverty reduction, to address different target-group of the society. They are- Food for Works programme, Vulnerable group Developed (VGD) programme, Old-Age Allowance Programme, Allowances Programme for Widowed, Deserted and Destitute Women and Honorarium Programme for Insolvent Freedom Fighters, Allowance for the Physically Handicapped and Seasonal Unemployment Reduction Allowance (100 day employment programme), Primary School Stipend Programmes etc. Side by side, the government is expanding 'Social Safety Net Programmes' and trying to revitalize micro credit programs, together with NGOs. According to a report ${ }^{48}$ social safety-net programmes have been proved to be one of the most successful programmes for keeping the hardcore poverty within manageable limit in the face of rising international prices during 2007-08 and recent global financial crisis.

The available statistics and study reports suggest a gradual reduction in poverty situation in Bangladesh. The analysis and evaluation of the contemporary policies and programs for poverty alleviation driven by governments side by side with NGOs suggest that they are not less qualitative. It is also observed that the RBA has not been fully and completely institutionalized in Bangladesh in making plans and strategies for poverty reduction program. However, the country is slowly incorporating core principles of the RBA when forced to adopt 'PRSP' prescribed by World Bank and to conform the requirement of donor groups.

Nevertheless, policy and programs for poverty alleviation in Bangladesh, to a larger extent, correspond with the human rights based approach, however, regretfully they finally meet an unlucky fate---not being able to reach the extreme poor and marginalized, which is the principal goal of the RBA. The failure is mostly due to structural injustice and weakness ${ }^{49}$. If we divide a poverty reduction program into two levels- (i) policy-making level, and (ii) implementation level, our major problem lies in the second phase. Local actors (Union Parishad, Upozila Parishad, Office of

\footnotetext{
${ }^{46}$ Economic Relations Division, Ministry of Finance, Government of Bangladesh, "Implementation in Asia and the Pacific of the Brussels Programme of Action for the Least Developed Countries for the Decade 2001-2010: progress made, obstacle encoounered and the way forward", Draft Country Review Paper presented at the 'Economic and Social Commission for Asia and the Pacific, 18-20 Jan 2010, p.9.

${ }^{47}$ Ibid, p. 9.

${ }^{48}$ Supra note-39.

${ }^{49}$ For details, see- S. A. Islam, 'Overcoming Poverty in Bangladesh: Search for a New Paradigm', Bangladesh e-Journal of Sociology, 2004, Vol. 1, No. 2.
} 
Deputy commissioner etc.) who are responsible for effective, fair and transparent implementation of a program are less efficient, corrupted, and politically biased. They take the upper layer of the benefits of the poverty alleviation programs. On the other hand, only resource-based poverty reduction programs may not always bring expected results unless policymaking and implementation processes are able to empower the poor. The planning and budgetary processes, if the country is mostly top-down, centralized and bureaucratic in nature may work in a resistive manner in empowerment of the poor. ${ }^{50}$

The RBA strongly advocates reformation of such local actors and more meaningful participation of beneficiaries in terms of voice-raise and getting redress to structural injustices. It also intermingle the neutral local actors such as NGOS, civil society, media and other non-profitable organization. Therefore, if the RBA is institutionalized in our poverty alleviation program and awareness is built from policy-makers to local level implementing authority, much of structural injustice and procedural failure or bureaucratic impediments can be eliminated. 'New Partnership for Africa's Development' (NEPAD), is a recently established organization for the purpose of, adopting a human-rights based approach to development at the regional level in Africa. It suggests a few concrete proposals ${ }^{51}$ for institutional reforms without which outcome of the RBA will be futile, i.e., administrative and civil services; strengthening parliamentary oversight; promoting participatory decisionmaking; adopting effective measures to combat corruption and embezzlement; and undertaking judicial reforms.

These reforms are also very relevant, contemporary and in a sense, compulsory in Bangladesh to accelerate speed of poverty alleviation. These reforms are also necessary to prevent corruption. A paper by OHCHR observers that-

It is self-evident that without peace and stability, there can be no hope of development. Without good governance, the poor are deprived of their right to participation and the presence of corruption is a tax on the poor. Corruption saps energy out of society and only heightens disparities and divisions within society. ${ }^{52}$

Therefore, without such reform in implementation level, even incorporating the RBA would be a mere paper-work in policy level only and Bangladesh cannot reach its desired goal in alleviating poverty. The other major difficulty in implementing poverty alleviation program in context of RBA is to ensure non-discrimination, equal

\footnotetext{
${ }^{50}$ Centre for Policy Dialouge (CPD), An Analysis of the National Budget: Allocation for the Ultra Poor, 23 March 2011.

${ }^{51}$ O. Nowsosad, A Human Rights Based Approach to Development: Strategies and Challenges, OHCHR, P.5.

${ }^{52}$ Ibid, P.6.
} 
and fair distribution of benefits of such programs. The vulnerable groups are addressed by some programs mentioned above but as a whole a large population is excluded from having benefits at all due to social inherent injustices, i.e., uplift of political consideration, nepotism, increasing disparity between rich and poor. The RBA also inspires to adequately deal with these social viruses through establishing rule of law, good governance, political stability, and fair and just distribution of income or benefits of economic growth. Therefore, vigorous attention should be placed upon how to achieve growth with fairness or equitable distribution of benefits of development. To this end, direct progressive income tax can be imposed on income and assets of the rich a portion of which may be added to the poverty reduction programs.

\section{Conclusion}

The examination of poverty shows that it cannot solely be seen in terms of figures for example whether there is insufficient income to buy a minimum basket of goods and services - rather one must look at the broader lack of basic capabilities to live in dignity. Poverty is about physical and economic insecurity, fear of the future and a constant sense of vulnerability. It is about lost opportunities and a sense of powerlessness. Accordingly, in order to address such situation of poverty, the 'Rights Based Approach' has been emerged as a conceptual framework to mainstream international human rights standards and norms, based on existing international human rights treaties and covenants, into poverty reduction policy making and implementation process.

Bangladesh has shown remarkable progress in poverty alleviation and it has been ahead of its many global counterparts in poverty indicators. ${ }^{53}$ Still, Bangladesh has substantial space to improve in poverty reduction efforts and to accelerate its current reduction rate by adopting the emerging conceptual framework, called 'Rights Based Approach' in its development agenda. To incorporate this emerging well-accepted concepts more fully in our poverty reduction programs and development agenda, the following suggestions are made-

a) The human rights-based approach must be institutionalized in poverty alleviation programs and projects in Bangladesh. It should be adopted duly at every step of the development projects, aiming to benefit the bottom line people to create a society based on equity and non-discrimination.

b) The awareness building efforts regarding the RBA should be taken among policy makers, government officials, elected peoples' representatives, and other concerned authorities. Efforts should also be taken to aware common people so that they have

${ }^{53}$ Supra note 46. 
proper and conscious knowledge regarding their rights and participation under the RBA.

c) Concrete and effective steps must be taken to remove political discrimination and corruption from the office of local actors. All feasible actions should be taken to this end. Different fitting programs in consideration of local context should be taken to make them more and more efficient.

d) Accountability, transparency and fairness must be ensured at all levels of the implementation process. Information regarding activities of all actors must be disseminated.

e) The government should find more effective ways to raise direct tax from the affluent of the country and to invest the accumulated public fund directly to poverty reduction programs. The state should take effective and stringent measures in order to ensure equal distribution of income and other resources, if necessary by passing laws in this behalf.

In fine, the people of Bangladesh dreams of a just society free from exploitation as envisaged by our Constitution. Poverty and income disparity are major impediments for establishing such a society. The Government must take effective steps in order to alleviate poverty. For this purpose, the observation and recommendations in this paper may be taken into account in formulating policy and implementation process for poverty alleviation programs. 